\title{
Application of sludge from urban wastewater treatment plants in road's embankments
}

\author{
By: Juan de Oña and Francisco Osorio
}

\author{
This document is a post-print versión (ie final draft post-refereeing) of the following \\ paper: \\ Juan de Oña and Francisco Osorio (2006) Application of sludge from urban wastewater \\ treatment plants in road's embankments. Journal of Hazardous Materials B131, 37-45. \\ Direct access to the published version: \\ http://dx.doi.org/10.1016/j.jhazmat.2005.07.082
}




\title{
Application of sludge from urban wastewater treatment plants in road's embankments
}

\author{
De Oña, J. and Osorio, $F^{*}$ \\ MITA Research Group; Department of Civil Engineering; University of Granada \\ *Corresponding author address.- Departamento de Ingeniería Civil; Universidad de Granada; \\ Campus de Fuentenueva, s/n; 18071; Granada - SPAIN; Telephone.- 34958249463; Fax.- \\ 34958246138; e-mail(corresponding author).- fosorio@ugr.es
}

\begin{abstract}
While different kinds of compost have been tested for highway revegetation, sewage sludge has only been used for agricultural purposes. In this work, its application for helping vegetation establishment on roads embankments is studied. Testing areas measuring $4 \times 5 \mathrm{~m}$ were constructed on a new highway embankment in an arid location. Several variables are analyzed: side slope (2); sludge dosage (4); and vegetative species (4). Results are presented on growth, survival rate and germination of the plants; colonization of other species; cover crop for the plots; and estimation of the erosion. The species planted manually showed satisfactory results although any variable was specially significant in this case. However, in relation to the species planted using hydroseeding, 2:1 side slope presented better results than 3:2 side slope. Using hydroseeding, the performance of different species was significantly different, thyme did not grow if sludge was not applied and the cover crop was higher in plots with 3:2 side slope than in plots with 2:1 side slope, essentially due to the presence of colonizing species. Finally, the costs of the proposed treatments are figured out, being concluded that, so much from the technical as the economic point of view, it is a viable proposal for sewage sludge management.
\end{abstract}

Key words: Sustainable development, erosion, roads embankments, urban waste, sludge from wastewater treatment plants 


\section{INTRODUCTION}

The World Commission on Environment and Development published the Brundtland Report in 1987. This document expressed the necessity to promote a sustainable development adapted to an ecological point of view. Since then, the European Union (EU) includes this topic in all of its policies, regulations and documents [1, 2].

The White Paper on the European Transport Policy for 2010: time to decide [2] highlighted the need to develop a sustainable transport. From this point of view, one of the main environmental impacts caused by road construction is slope degradation taking to erosion on road embankments [3]. The most important factor that influences erosion is cover crop [4, 5].

Highway planning and project design of roads embankments and other linear engineering projects are no longer limited by the traditional problems of stability. Nowadays landscape integration, vegetation recovery and reduction of soil loss caused by erosion are parameters which are as important as geotechnical ones [6].

Vegetation has several favourable effects to protect slopes from erosion. Cover crop blocks and retains water coming from rainfall and splash erosion decreases. The infiltration rate is greater in soils with plants than in soils without them [7]. These effects, together with evapotranspiration ${ }^{1}$, permit the reduction of free water on the surface and, therefore, protecting the slope from surface runoff. Other effects include: modification of natural properties and soil fastening thanks to the roots, which create an intimately linked fibre frame; protection from traffic; and isolation, because a microclimate that reduces temperature and humidity variations is created on the soil surface. Thus, there is a decrease in the natural weathering process.

So plants have a very important role in erosion control and slope stabilization. However, the characteristics of the embankments are not usually suitable for plants since materials are basically selected according to their resistance characteristics.

On the other hand, humans generate so much waste and so many by-products. Traditional solutions in waste management such as dumping sites or incineration are questioned for

1 The term evapotranspiration is used to describe the water loss group in vapor caused by evaporation of the rain intercepted by plants and caused by plants transpiration [6]. 
several reasons $[8,9]$ : dumping sites are dangerous because they can affect subsoil water and incineration is an emission source and it is very pollutant in some cases.

Therefore, these waste management measures are being restricted by EU directives. These measures have prompted the research for new environmental solutions in the EU even although the society may incur some recycling costs.

EU has been working towards recycling materials on highways construction for a number of years. Clients should accept recycled materials in civil engineering as long as their characteristics are the same as those of conventional ones [10]. They should be non volatile, volumetrically stable and non noxious leached.

Many products have been researched and some of them have already been accepted in engineering $[10,11]$ :

- Road building waste: materials from road surface layers, quarry oversize and from mineral dust of bituminous mixture factories.

- Industrial waste: thermal power station ashes, iron and steel industry ashes and mine dead, mainly from coal.

- Urban waste: urban incinerator ashes, used tyres, demolition wastes, used engine oils, waste plastic and glass.

- Organic waste: Olive vegetable waters.

The waste management problems are becoming worse in town environments because of building up of urban areas. Obligatory by-products are generated in treatment lines, but they are not reused, such as sludge and compost. These by-products are the result of operational wastewater treatment plants and recycling and composting plants all over the world.

Both of these problems (erosion in road embankments and urban waste management) seem to be unrelated but, if fertilizing capacity of by-products $[12,13,14]$ and the need to improve the agronomic properties of highway embankments materials are considered together, it show up that they are related and their combination could solve partially both problems. Waste fertilization capacity helps cover crop growth and it reduces erosion. 
Thanks to this new point of view urban waste management could have roads as one of their major customers [11, 15]. This new domain has been barely analyzed before. Recently some literature has appeared in relation to the environmental effects of applying urban wastes to highway embankments $[16,17,18]$, but further work need to be done.

This project was designed to study the viability of sludge use for revegetating highway embankments. So, the main raised objectives were the following:

A) To assess the plant growth and analyse the technical and economic viability.

B) Study of the influence of design parameters on embankments following revegetation criteria, not only mechanics criteria.

C) To establish the benefits obtained due to soil fixation, assessing erosion.

The research methodology followed 4 main phases: (1) Study and analysis of basic variables;

(2) Experiment design and execution; (3) Process follow up and control; and (4) Analysis of results.

\section{MATERIALS AND METHODS}

\subsection{STUDY AND ANALYSIS OF VARIABLES}

In this phase, the main objective was to identify and define the variables that have some influence in the research to optimize the tests to be carried out. Every considered variable is described and justified next:

\subsubsection{Location and orientation}

The experiment was carried out in a semi-arid environment, which is characterized by high climate erosivity - little but intense rainfall - and limited vegetation, where erosion processes make a big impact.

A highway embankment in the Waste Recycling and Composting Plant of Gádor (Almeria, South of Spain) was selected. The location assured a complete access control to the area and low traffic. So the location was optimum to guarantee an exhaustive control of the research conditions, facility in work conditions and the orientation that was wanted for the tests. The embankment was orientated South-East, which was considered as appropriate in relation to the 
climate harshness.

Climate is a typically dry Mediterranean climate [19]. It has an average annual precipitation of $219 \mathrm{~mm}$, raining during the winter and the autumn and at the beginning of spring. Winds come from the coast area, the West-Southwest, but most of the terrain is protected by the Gádor mountains. Wind from the East is also frequent, especially in summer, and it is so hot that it produces major dehydrations. Winds from the North enter this area and produce temperatures near to $0^{\circ} \mathrm{C}$ during some of the winter months. Maximum and minimum registered temperatures during the last 63 years are $42^{\circ} \mathrm{C}$ and $0.2^{\circ} \mathrm{C}$, with a relative humidity of $73 \%[19,20]$.

\subsubsection{Embankments slopes}

The 3:2 and the 2:1 are standardized and they are the most used slopes in road embankments due to geotechnical factors. The first one complies with enough security requirements for a great variety of soils and it reduces the total surface of occupation and the final earth moving cubage. The second one is used mainly for security requirements with very loose unconnected materials and with very little internal friction, or for environmental reasons. Tests have been carried out in both slopes to analyze its influence on the results.

\subsubsection{Characteristics of soil and sludge used in the embankment}

The material used in the embankments, which came from an excavation from the dumps in the waste plant, was classified as silty sands suitable for use in the embankment core (see table 1). However, its agronomic characteristics were very limited (see table 2).

(TABLE 1)

Complete analyses of these products were made to assess their fertilizing capacity and to check their heavy metals content as well as to check that their microbiological parameters do not exceed the threshold marked by legislation (see tables 2 and 3 ).

No current regulations exist for the application of sludge in roads embankments because this is the first time sludge has been used for it, on the basis of the bibliographic review. The most approximate use for biosolids to this proposal that has been reported is the application on soils [8]. Thus, agriculture regulations have been taken into account as reference, since agriculture is 
a closely and a well known related domain [22, 23].

Thus, the Council Directive of 12 June 1986 on the protection of the environment, and in particular of the soil, when sewage sludge is used in agriculture (86/278/EEC) [24] has been used as a reference for sludge regulation. In Table 2, the $3^{\text {rd }}$ European Directive Draft [25] is shown as more restrictive than current legislation and sludge samples values are lower than maximum values established by both documents in each case. Limitations imposed by directive drafts include microbiological parameters.

(TABLE 2)

(TABLE 3)

\subsubsection{Dosage of sludge}

Four plots for each considered side slope (3:2 and 2:1) were used and dosages were applied as shown in Table 4. Three dosages for sludge have been used (60, 80 and $100 \mathrm{t} / \mathrm{ha})$.

(TABLE 4)

These dosages are typical in the agriculture domain $[12,13,26]$ in accordance with the values reported in different bibliographic references dealing with sewage sludge application. Of course, the objectives in these studies took into account the protection against negative effects, the same which are raised in this work.

\subsubsection{Species selection}

Species selection was made on the basis of biotechnical and environmental criteria and fitosociological considerations. Autochthonous species of local plants were selected. There was a large presence of wild plants near the Gádor plant presenting a good capacity to adapt for negative conditions.

Several species were selected in order to analyze the growth capacity of each one of them and

to test different procedures in their application. Selected species were: esparto (Stipa tenaccisima), thyme (Thymus capitatus), genista (Genista umbellata) and broom (Retama monosperma).

\subsubsection{Experiment plot dimensions}

The dimension of the used plots had a width of $4 \mathrm{~m}$, level with the road, and length of $5 \mathrm{~m}$ in the 
direction of maximum slope of the embankment (see figure 1). This dimension was well related to the species size and the dimensions assuring an appropriate development of the work.

(FIGURE 1)

\subsubsection{Planting characteristics}

There were two different planting processes. Hydroseeding was used for esparto and thyme. Planting dosage was $2.5 \mathrm{~g} / \mathrm{m}^{2}$ for each species and a previous shelling was made before applying the seeds. The total quantity of seed was $320 \mathrm{~g}$, taking into account the two plot series and the $20 \mathrm{~m}^{2}$ of surface of each plot.

Manual planting was applied for genista and broom. The planting frame was $1 \mathrm{~m} \times 1 \mathrm{~m}$ and planting was triangular (see Figure 1). Neither of the plants had another one of the same species beside it. In both cases the whole plant with roots came from a nearby nursery in plastic cells as it is usual in highway construction sites. The total number of plants used was 20 (10 of each species) in each plot. The total was 80 units of genista and 80 of broom.

\subsection{DESIGN AND EXECUTION OF THE EXPERIMENT}

For the experimental phase, the starting point was that the same tools that those available for road construction should be use for the tests.

Parcels were prepared on the embankment of the road that connects the selection and sorting warehouse with the fermentation and purification warehouse (see Figure 2) in the plant. This road has one of its embankments on a slope that was higher than needed, so a $5 \mathrm{~m}$ wide intermediate berm was built at the edge of the experiment banks.

\section{(FIGURE 2)}

In the lower part of the bank 4 plots were made with a slope of 2:1. A land length of $30 \mathrm{~m}$ was left to execute a soft transition in the slope and the rest of the plots were made with a 3:2 side slope.

In order to avoid water from outside the slope affecting the experiment, a ditch on the top of the slope with a small earth ridge was made. It behaved very satisfactorily during the experiment.

Once the banks were made, sludge was applied manually. First of all dehydrated sludge was 
put in place. It was a viscous and plastic-like material that was difficult to handle (see Figure 3).

(FIGURE 3)

As mentioned above, two species were planted manually and other two through hydroseeding. Since manual planting required working stepping on the bank slope, the manual planting of broom and genista was made first and later hydro-seed esparto and thyme. The only care given and maintenance done to plots was irrigation during the first three weeks after sowing.

\subsection{PROCESS FOLLOW UP AND CONTROL}

Parameters measured during research were:

- Survival rate. For the two species planted manually survival rate (percentage of plants alive) was recorded weekly.

- Plant growth. For the two species planted manually growth percentage was recorded weekly. The height of every plant alive was measured manually using a standard ruler with millimetre accuracy.

- Plant germination. Fortnightly, germinated plants per $\mathrm{m}^{2}$ were counted in the case of thyme and esparto.

- Colonization by other species. Each month colonizing plants per $\mathrm{m}^{2}$ were counted (not planted species that had developed without control).

- Cover crop per plot. It was measured taking a digital picture of every analyzed plot.

- Erosion estimation. Erosion has been studied using the Universal Soil Loss Equation [27] that has been considered the base for other later formulations and recognized as the one that best approximates the physical phenomenon. Several international and national organisms (EU, UNESCO, ICONA, etc.) have used this formulation for estimating erosion all over the world $[28,29]$.

- Sampling and analysis for soil and sludge examination. The sampling and analysis of the most relevant parameters were carried out as given by CEN standards to the date at the research moment. If CEN standards were not available, ISO, international or national standards were applied. 


\section{RESULTS AND DISCUSSION}

From the date of plantation a follow up of vegetation species took place. Next the analysis of the obtained results in the last measurement is presented.

Genista survival rate was very irregular (see Figure 4), contrasting with the high values obtained, more satisfactorily, by broom (Figure 4). Average survival rate of genista was $55 \%$ (Standard Deviation -S.D.- 13.1), while broom had an average rate of $84 \%$ (S.D. 11.9).

(FIGURE 4)

For both species average height at the time of planting was $25 \mathrm{~cm}$, with S.D. 1.21 for genista and S.D. 1.19 for broom. The height of both species in the last measurement is presented in Figure 5. This figure shows that growth was slightly higher for genista than for broom. These results, together with the survival rate, don't allow to establish conclusions about which species is preferable for manual plantation. Genista presents lower survival rates but higher growth than broom.

(FIGURE 5)

As can be seen from the results for the species planted manually, survival and growth results were practically independent of the slope.

Nevertheless, in the case of hydroseeding different results were noticed relating to the slope. Thyme germination was much higher in 2:1 side slope than in 3:2 side slope (see Figure 6). In the case of esparto, germination was very low in both slopes, although better performance can be seen in the 2:1 side slope (see Figure 6).

\section{(FIGURE 6)}

It can be inferred that thyme did not germinate in plots were there was a total absence of applied sludge (plots 1 and 5).

The relative total germination of both species (thyme and esparto) is shown in Figure 7. Relative total germination is the ratio of the germination of thyme and esparto for a particular treatment to that of the reference plot -without application of sludge- for each side slope (plot 1 for 2:1 side slope and plot 5 for 3:2 side slope). The largest relative total germination was for plots with 
2:1 side slopes presenting values between 23.29 and 13.57 . For $3: 2$ side slopes plots values were between 4.55 and 1.00. For each slope, plots with sludge treatments always presented total germination higher than the reference plots.

(FIGURE 7)

Natural colonization by other species was denser in plots with 3:2 side slope than in plots with 2:1 side slope (plot 1 presented 0.3 plants $/ \mathrm{m}^{2}$ while plot 5 presented 6.1 plants $/ \mathrm{m}^{2}$ ). This seems to be due to the fact that this bank was closer to the plot that had not been ploughed (see Figure 1), as dependence to slope cannot be inferred from data for the majority of planted species.

Figure 8 shows relative colonization for both slopes and the different treatments. Relative colonization is the ratio of colonization by other species for a particular treatment to that of the reference plot -without application of sludge- for each side slope. For both slopes the largest relative colonization was for plots with a sludge dosage of $60 \mathrm{t} / \mathrm{ha}$. Just like in the case of germination (see Figure 7), plots with 2:1 side slope are more sensitive to sludge treatment than plots with 3:2 side slope.

(FIGURE 8)

Species used in the experiment (genista, broom, thyme and esparto) have competed with the colonizing species for space, water and nutrients to give the plot cover crop.

Vegetative cover was higher in 3:2 side slope plots than in 2:1 side slope plots essentially due to the presence of the aforesaid colonizing species. While vegetation only covered $12 \%$ in plot 1 (the lowest of the eight plots), $25 \%$ of surface was covered in plot 5 . Plot 8 presents the largest vegetation cover with $51 \%$ of surface covered.

The relative vegetative cover is shown in the left graph of Figure 9. Relative vegetative cover is the ratio of the vegetative cover for a particular treatment to that of the reference plot -without application of sludge- for each side slope. This figure shows much more coverage in all plots where sludge was applied than in the reference or base plots ( 1 and 5), that is to say, where no by-product had been applied.

(FIGURE 9) 
Erosion estimation was figured out with the Universal Soil Loss Equation [27]:

$$
A=R \cdot K \cdot L \cdot S \cdot C \cdot P
$$

Where: A: soil loss (t/ha·year)

R: rainfall erosivity index $\left(\mathrm{J} \cdot \mathrm{cm} / \mathrm{m}^{2} \cdot \mathrm{h}\right)$

$\mathrm{K}$ : soil erodibility factor $\left(\mathrm{t} \cdot \mathrm{m}^{2} \cdot \mathrm{h} / \mathrm{ha} \cdot \mathrm{J} \cdot \mathrm{cm}\right)$

L: $\quad$ slope length (non dimensional)

S: bank slope factor (non dimensional)

C: cropping factor (non dimensional)

P: conservation practice factor (non dimensional)

The Food and Agriculture Organization (FAO) of the United Nations developed experimental formulations to determine all these factors [29]. Several studies have adapted this formulation to the particular climate conditions in Spain [28, 30, 31]. Rainfall erosivity, soil erodibility, slope length and conservation practice factors have been kept constant for the 8 plots (see Table 5). Differences in the results are due to the bank slope factor for each of the different inclinations, and for the cropping factor obtained from the percentage of existing cover crop [28], interpolated in Table 6 taking into account each plot's percentage.

(TABLE 5)

(TABLE 6)

The relative soil loss is shown in the right graph of Figure 9. Relative soil loss is the ratio of the soil loss for a particular treatment to that of the reference plot -without application of sludge- for each side slope. The largest soil loss was for plots 1 and 5 (72 and 71 t/ha·year respectively). Plot 8 presented the lowest soil loss with 10 t/ha·year. This figure shows that more cover crop implies less soil loss.

Below the costs of the application of bio-solids in road embankments are figured out and compared with the present costs of road embankments revegetation processes.

In Table 7 the costs for the Administration in application of sludge in a road embankment in 
euros per dry metric ton are shown. There are costs of transport of bio-solids, water for irrigation and manipulation. Sludge also incurs a dehydration cost, although it could also be applied in its liquid form. Sludge is free because it is an obligated by-product at the end of treatment lines. In order to establish transport costs an average distance of $40 \mathrm{~km}$ has been considered.

(TABLE 7)

Taking all these factors into account, sludge has an average gross cost of $246.13 €$ per dry metric ton. However, the use of this product in road embankments saves society some money due to reduction of dumping. That is why if this saving is deducted from the costs outlined above, the net sludge cost for the Administration would be of $152.68 €$ per dry metric ton.

Maximum dosage used for sludge in the experiment has been 100t/ha (24 dry metric tons per hectare). This amount implies $3664 € /$ ha for the aforesaid dosage of sludge.

In Table 8 the average cost of traditional hydroseeding treatment on roads is figured out, just as its repercussion in the road budget, including the cost of treatments in which biosolids are used. As can be seen in this table, seeds are the most expensive item of the budget.

(TABLE 8)

Comparing to traditional methods $50,000 € /$ ha ( $4 \%$ of the road's total budget), treatments that use sludge would cost about $3,600 € /$ ha $(0.3 \%$ of the road's total budget).

\section{CONCLUSIONS AND RECOMMENDATIONS}

In relation to the agronomic parameters, both species planted manually showed satisfactory results:

- The genista and broom survival rates were $55 \%$ and $84 \%$, respectively.

- The side slope variable was not specially significant in this case.

- In the same way, the fact of the addition of sludge was not significant to get better results. Indeed, plots without addition of sludge presented survival rates of $55 \%$ and 90 $\%$ for genista and broom, respectively.

However, in relation to the species planted using hydroseeding, the performance of different species was significantly different: 
- The germination of thyme achieved a maximum value of about $7 \mathrm{plants} / \mathrm{m}^{2}$, whereas the germination of esparto was much lower, achieving a maximum value lightly higher than 1 plants $/ \mathrm{m}^{2}$.

- For both species, plots with 2:1 side slope presented better results than plots with 3:2 side slope

- Thyme did not grow if sludge was not applied.

For both plantation procedures, vegetation cover was higher in the plots with 3:2 side slope, corresponding with an average value of $35 \%$, than in the plots with $2: 1$ side slope, presenting an average value of $15 \%$. This is essentially due to the presence of the aforesaid colonizing species.

\section{RECOMMENDATIONS AND GENERAL COMMENTS}

Until now, sludge was never considered as material for road construction. Nevertheless, this research shows that the application of these biosolids in roads embankments increases cover crop. With low seed dosages a high cover crop can be achieved. This increase in cover crop has a direct effect in erosion reduction in the embankments and therefore in the environmental impacts caused by the roads construction.

Given the positive results obtained, the use of sewage sludge in road embankments must be encouraged. The treatment cost without vegetal species is very low, and application of biosolids should be imposed by including them in construction projects. This would also imply more durable roads with higher landscape value and less soil loss.

Due to the innovation of this application, there is no specific set of regulations to date. Heavy metals content just as microbiological parameters for the used sludge in the research are in accordance with the agriculture legislation that is currently in force or as a draft, and that should be more restrictive for that area than for the proposed use in this research. Therefore, it can be concluded that this application does not represent any threat to public health.

In this research dehydrated sludge has been used, which has seriously incremented manipulation costs. It has been estimated than the use of liquid sludge could be more efficient, 
even although transportation costs are higher, since manipulation and irrigation costs would be lower and there is no dehydration cost.

\section{REFERENCES}

[1] European Commission. Environmental Policy Review, Commission of the European Communities, Brussels, 2003.

[2] European Commision. European transport policy for 2010: time to decide, Commission of the European Communities, Brussels, 2001.

[3] J. Grace. Erosion control techniques on forest road cutslopes and fillslopes in north Alabama, Transportation Research Record 1652 (1999): 227-324.

[4] R. Morgan. Erosión y conservación del suelo, Ed. Mundi-Prensa, Madrid, 1997.

[5] D. Block. Controlling erosion from highway projects, Biocycle 41(1) (2000), 59-62.

[6] N. Coppin, I. Richards. Use of Vegetation in Civil Engineering, CIRIA Water Engineering Report, Butterworths, London, 1990.

[7] L. Meyer, W. Wischmeier, W. Daniel. Erosion, runoff and revegetation of denuded construction sites, Transaction of the ASAE 24(6) (1971), 1472-1475.

[8] K. Cameron, H. Di, R. Mclaren. Is soil an appropriate dumping ground for our wastes?, Australian Journal of soil research 35(5) (1997):995-1035.

[9] A. Belmonte. Reutilización y reciclado de materiales. Experiencia en Andalucía, Ed. Asociación Española de la Carretera, III Congreso Andaluz de Carreteras, Madrid, Spain, 2003, pp. $143-185$.

[10] A. Ruiz. Experiencias en España con la utilización de residuos y de materiales secundarios en carreteras, Carreteras 118 (2001): 8-25.

[11] S. Mathur, S. Soni, A. Murty. Utilization of industrial wastes in low-volume roads, Seventh Intenational Conference on Low-Volume Roads 1652 (1999): 246-256.

[12] F. Amlinger, B. Gotz, P. Dreher, J. Geszti, C. Weissteiner. Nitrogen in biowaste and yard waste compost: dynamics of mobilisation and availability, European Journal of Soil Biology 
39(3) (2003): 107-116.

[13] A. Andreadakis, D. Mamais, E. Gavalaki, S. Kampylafka. Sludge utilization in agriculture: possibilities and prospects in Greece, Water Science and Technology 46(10) (2002): 231-238.

[14] M. Polo. Uso agrícola de lodos de depuradoras. Consejería de Agricultura y Pesca de la Junta de Andalucía, Sevilla, Spain, 1997.

[15] M. Aziz, L. Koe. Potential utilization of sewage-sludge, Water Science and Technology 22(12) (1990): 277-285.

[16] R. Persyn, T. Glanville, T. Richard, J. Laflen, P. Dixon. Environmental effects of applying composted organics to new highway embankments: Part 1. Interrill runoff and erosion, Transactions of the ASAE 47(2) (2004):463-469.

[17] T. Glanville, R. Persyn, T. Richard, J. Laflen, P. Dixon. Environmental effects of applying composted organics to new highway embankments: Part 2. Water quality, Transactions of the ASAE 47(2) (2004):463-469.

[18] S. Benik, B. Wilson, D. Biesboer, B. Hansen, D. Stenlund. Performance of erosion control products on a highway embankment, Transactions of the ASAE 46(4) (2003):1113-1119.

[19] F. Rueda. Ecosistema de la vega del bajo Andarax, Ed. Confederación Española de Cajas de Ahorro, Madrid, 1987.

[20] Las Palmerillas Meteorological Station. http://www.laspalmerillas.cajamar.es. (2003). (Meteorological daily data from 1976).

[21] Ministerio de Fomento. PG-3. Pliego de Prescripciones Técnicas Generales para Obras de Carreteras y Puentes. First Edition. Madrid, Spain, 1976.

[22] J. Berger, A. Boss, H. Fehrenbach, F. Knappe, R. Vogt. Assesment of agricultural production from a waste management standpoint, Berichte Uber Landwirtschaft 81(2) (2003): 269-301

[23] R. Muchovej, R. Pacovsky. Future directions of by-products and wastes in agriculture, Agricultural uses of by-products and wastes, ACS Symposium Series 668 (1997): 1-19.

[24] Council Directive of 12 June 1986 on the protection of the environment, and in particular of 
the soil, when sewage sludge is used in agriculture (86/278/EEC)

[25] European Commission. Working Document on Sludge, 3rd Directive Draft. Brussels, 27 April 2000

[26] F. García, J. Martínez, I. Gómez, J. Mataix. Evolución foliar de Macronutrientes (N, P, K, $\mathrm{Ca}, \mathrm{Mg}, \mathrm{Na}$ ) en olivos fertilizados con lodos de depuradora, VI Congreso Hispano-Luso de Fisiología Vegetal, Sevilla, Spain, 1999.

[27] U.S. Department of Agriculture. Agriculture Handbook 282, 1958.

[28] J. Aguilo. Tratado del medio natural. Causas de destrucción del suelo, Tomo I, Ed. UPM, CEOTMA, INIA e ICONA, Madrid, Spain, 1981, pp. 499-559.

[29] United Nations. FAO. Guidelines for Soil Profile Description. Food and Agriculture Organization, $3^{\text {rd }}$ Edition. 197290.

[30] M. González. La Ecuación Universal de Pérdidas de Suelo. Pasado, presente y futuro. Ecología 5 (1991): 7-28.

[31] ICONA. Agresividad de la lluvia en España. Valores del Factor R de la Ecuación Universal de Pérdidas de Suelo. Madrid, Spain, 1988. 
Table 1. Characteristics of soil

\begin{tabular}{|c|c|c|c|c|}
\hline Particle size distribution & $\begin{array}{l}\text { Sieve } \\
(\mathrm{mm})\end{array}$ & \%Passing & $\begin{array}{l}\text { Sieve } \\
(\mathrm{mm})\end{array}$ & \%Passing \\
\hline \multirow{7}{*}{$\begin{array}{l}\text { UNE EN 933-2: from } 40.00 \mathrm{~mm} \text { to } 0.080 \mathrm{~mm} \\
\text { UNE 103102: from } 0.056 \mathrm{~mm} \text { to } 0.002 \mathrm{~mm}\end{array}$} & 40.00 & 100.0 & 0.400 & 26.3 \\
\hline & 25.00 & 95.9 & 0.080 & 19.7 \\
\hline & 20.00 & 93.4 & 0.056 & 17.6 \\
\hline & 12.50 & 81.3 & 0.028 & 14.4 \\
\hline & 10.00 & 77.5 & 0.010 & 11.2 \\
\hline & 5.00 & 62.5 & 0.007 & 8.0 \\
\hline & 2.00 & 48.3 & 0.002 & 4.8 \\
\hline Others parameters & \multicolumn{2}{|c|}{ Obtained values } & \multicolumn{2}{|c|}{ Limits $\left(^{*}\right)$} \\
\hline Organic material content (UNE 103204) & \multicolumn{2}{|l|}{$0.32 \%$} & \multicolumn{2}{|l|}{$<2 \%$} \\
\hline Gypsum content (NLT 115) & \multicolumn{2}{|l|}{$0.41 \%$} & \multicolumn{2}{|l|}{$<5 \%$} \\
\hline Other soluble salt content (NLT 114) & \multicolumn{2}{|l|}{$0.42 \%$} & \multicolumn{2}{|l|}{$<1 \%$} \\
\hline Liquid limit (UNE 103103) & \multicolumn{2}{|l|}{$30.2 \%$} & \multicolumn{2}{|l|}{$<65 \%$} \\
\hline
\end{tabular}


Table 2.a Heavy metals in soil and sludge samples, and maximum admitted values when sewage sludge is used in agriculture (Directive 86/278/EEC [29] and $3^{\text {rd }}$ Directive Draft [30])

\begin{tabular}{|c|c|c|c|c|c|c|c|}
\hline Values in mg/kg & Cadmium & Cooper & Nickel & Lead & Zinc & Mercury & Chromium \\
\hline Soil $\left(^{*}\right)$ & 2.28 & $<1$ & 2.52 & 9.93 & $<0.5$ & 0.21 & 4.19 \\
\hline Sludge $\left(^{*}\right)$ & 3.82 & 230.50 & 19.10 & 38.66 & 577.00 & 8.59 & 23.23 \\
\hline Directive 86/278/EEC & 40 & 1750 & 400 & 1200 & 4000 & 25 & 1500 \\
\hline $3^{\text {rd }}$ Directive Draft & 10 & 1000 & 300 & 750 & 2500 & 10 & 1000 \\
\hline
\end{tabular}

Table 2.b Agronomic parameters in soil and sludge samples

\begin{tabular}{|c|c|c|c|c|c|}
\hline Parameter & Soil & Sludge & Parameter & Soil & Sludge \\
\hline Moisture content (\%) & 1.97 & 75.85 & Iron $(\mathrm{mg} / \mathrm{kg})$ & 2.00 & 106.57 \\
\hline Real Density $(\mathrm{g} / \mathrm{mL})$ & 2.76 & 1.27 & Total Nitrogen $(\mathrm{mg} / \mathrm{kg})$ & 650.98 & 99151.9 \\
\hline Apparent Density $(\mathrm{g} / \mathrm{mL})$ & 1.38 & 0.54 & Nitrogen-Nitric $(\mathrm{mg} / \mathrm{L})$ & 10.75 & $<0.5$ \\
\hline $\mathrm{pH}$ & 8.61 & 7.26 & Nitrogen-ammoniacal $(\mathrm{mg} / \mathrm{L})$ & 5.18 & 378.47 \\
\hline Organic Matter (\%) & 0.32 & 9.92 & Phosphorous- $\mathrm{P}_{2} \mathrm{O}_{5}(\mathrm{mg} / \mathrm{L})$ & 6.84 & 100.63 \\
\hline Dry Matter $(\%)$ & 98.03 & 24.15 & Potassium- $\mathrm{K}_{2} \mathrm{O}(\mathrm{mg} / \mathrm{L})$ & 20.8 & 377.50 \\
\hline Conductivity $(\mu \mathrm{s} / \mathrm{cm})$ & 4.20 & 11.59 & Sulphate $(\mathrm{mg} / \mathrm{L})$ & 533.98 & 4376.46 \\
\hline Humic Extract $(\%)$ & 0.06 & 3.28 & Calcium-CaO $(\mathrm{mg} / \mathrm{L})$ & 98.9 & 315.6 \\
\hline Humic Acids (\%) & 0.02 & 1.06 & Magnesium-MgO (mg/L) & 122.8 & 527.1 \\
\hline Fulvic Acids (\%) & 0.04 & 2.22 & Sodium- $(\mathrm{mg} / \mathrm{L})$ & 654.1 & 601.5 \\
\hline C:N Ratio & 4.95 & 2.26 & & & \\
\hline
\end{tabular}


Table 3. Checking of microbiological parameters contents in sludge

\begin{tabular}{|c|c|c|c|}
\hline \multirow{2}{*}{$\begin{array}{c}\text { Microbiological } \\
\text { parameter }\end{array}$} & \multicolumn{2}{|c|}{ Maximum admitted values } & \multirow{2}{*}{$\begin{array}{l}\text { Sludge Sample } \\
\text { concentrations }\end{array}$} \\
\hline & Directive 86/278/EEC $\left(^{*}\right)$ & $3^{\text {rd }}$ Directive Draft $\left({ }^{* *}\right)$ & \\
\hline Salmonella & No established limit & $\begin{array}{c}\text { To be considered an } \\
\text { advanced treatment: } \\
\text { Absence in } 50 \mathrm{~g} \text { (wet } \\
\text { weight) in treated sludge }\end{array}$ & Absence \\
\hline Fecal Coli & No established limit & $\begin{array}{c}\text { To be considered an } \\
\text { advanced treatment: } \\
<500 \text { Escherichia Coli } \\
\text { CFU/g in treated sludge } \\
\text { and at least } 6 \text { Log }_{10} \\
\text { reduction } \\
\text { To be considered an } \\
\text { conventional treatment: } \\
\text { At least } 2 \text { Log }_{10} \text { reduction }\end{array}$ & $<10$ \\
\hline
\end{tabular}

$\left({ }^{*}\right)$ At the present moment, there are not established limits for microbiological parameters in the sludge.

$\left.{ }^{* *}\right)$ There are not established limits for the microbiological parameters in the sludge to be applied, the microbiological parameters limits are only used to determine the type of treatment applied to the sludge in the wastewater treatment plant. This is important in order to define the authorized uses for the sludge. 
Table 4. Plot number and sludge dosage in the experiment

\begin{tabular}{|l|rrrr|rrrr|}
\hline Bank & \multicolumn{3}{|c|}{$2 \mathrm{H} / 1 \mathrm{~V}$} & \multicolumn{5}{c|}{$3 \mathrm{H} / 2 \mathrm{~V}$} \\
\hline Plot & 1 & 2 & 3 & 4 & 5 & 6 & 7 & 8 \\
\hline Sludge (t/ha) & 0 & 100 & 80 & 60 & 0 & 100 & 80 & 60 \\
\hline
\end{tabular}


Table 5. Factors $R, K, L, S$ and $P$.

\begin{tabular}{|c|c|c|c|c|c|}
\hline \multirow{2}{*}{$\mathbf{R}$} & \multirow{2}{*}{$\mathbf{K}$} & $\mathbf{L}$ & \multicolumn{2}{|c|}{$\mathbf{S}$} & \multirow{2}{*}{$\mathbf{P}$} \\
\cline { 4 - 5 } & & & $\mathbf{2 H} / \mathbf{1 V}$ & $\mathbf{3 H} / \mathbf{1 V}$ & \\
\hline 51,10 & 0,3362 & 0,41 & 18,57 & 31,96 & 0,90 \\
\hline
\end{tabular}


Table 6. $C$ factors related to the cover crop percentage

\begin{tabular}{|c|c|c|c|c|c|}
\hline Coverage \% & C & Coverage \% & C & Coverage \% & C \\
\hline 5 & 0.807 & 35 & 0.129 & 65 & 0.017 \\
\hline 10 & 0.613 & 40 & 0.086 & 70 & 0.012 \\
\hline 15 & 0.466 & 45 & 0.065 & 75 & 0.009 \\
\hline 20 & 0.319 & 50 & 0.045 & 80 & 0.006 \\
\hline 25 & 0.242 & 55 & 0.034 & 90 & 0.003 \\
\hline 30 & 0.166 & 60 & 0.023 & 100 & 0.001 \\
\hline
\end{tabular}


Table 7. Costs of sludge application in a road embankment

\begin{tabular}{|l|c|}
\hline & $\begin{array}{c}\text { Sludge } \\
\text { (€/Dry metric ton) }\end{array}$ \\
\hline Dehydrating & 94.11 \\
\hline Buy at fabrication premises & 16.60 \\
\hline Transport of the biosolid & 31.25 \\
\hline Irrigating water transport & 104.17 \\
\hline Manipulation & $\mathbf{2 4 6 . 1 3}$ \\
\hline TOTAL (Gross cost) & 93.45 \\
\hline Saving due to reduction in dumping costs & $\mathbf{1 5 2 . 6 8}$ \\
\hline TOTAL (Net cost for the Administration) & \\
\hline
\end{tabular}


Table 8. Costs of different roads embankments treatments

\begin{tabular}{|c|c|c|}
\hline Treatment & Cost $(€ /$ ha) & Road budget \% \\
\hline $\begin{array}{c}\text { TRADITIONAL HYDROSEED } \\
\text { Seeds: } 150 \mathrm{~kg} / \mathrm{ha}\end{array}$ & $50,000 € / \mathrm{ha}$ & $4.00 \%$ \\
\hline $\begin{array}{l}\text { LOW COST HYDROSEED } \\
\text { Seeds: } 50 \mathrm{~kg} / \mathrm{ha} \\
\text { Sludge: } 100 \mathrm{t} / \mathrm{ha}\end{array}$ & $18,664 € / \mathrm{ha}$ & $1.49 \%$ \\
\hline $\begin{array}{l}\text { SLUDGE } \\
\text { Sludge dosification: } 100 \mathrm{t} / \mathrm{ha}\end{array}$ & $3,664 € / \mathrm{ha}$ & $0.29 \%$ \\
\hline
\end{tabular}




\section{FIGURE CAPTIONS SHEET}

Figure 1. Plot dimensions and planting of genista and broom

Figure 2. General view of the experiment area

Figure 3. Detail of applied sludge

Figure 4. Plot number Vs. Survival rate of genista and broom (\%)

Figure 5. Plot number Vs. Growth of genista and broom

Figure 6. Plot number Vs. Germination of thyme and esparto (in plants per $\mathrm{m}^{2}$ )

Figure 7. Relative total germination (thyme + esparto)

Figure 8. Relative colonization by others species

Figure 9. Relative percent vegetative cover and soil loss 


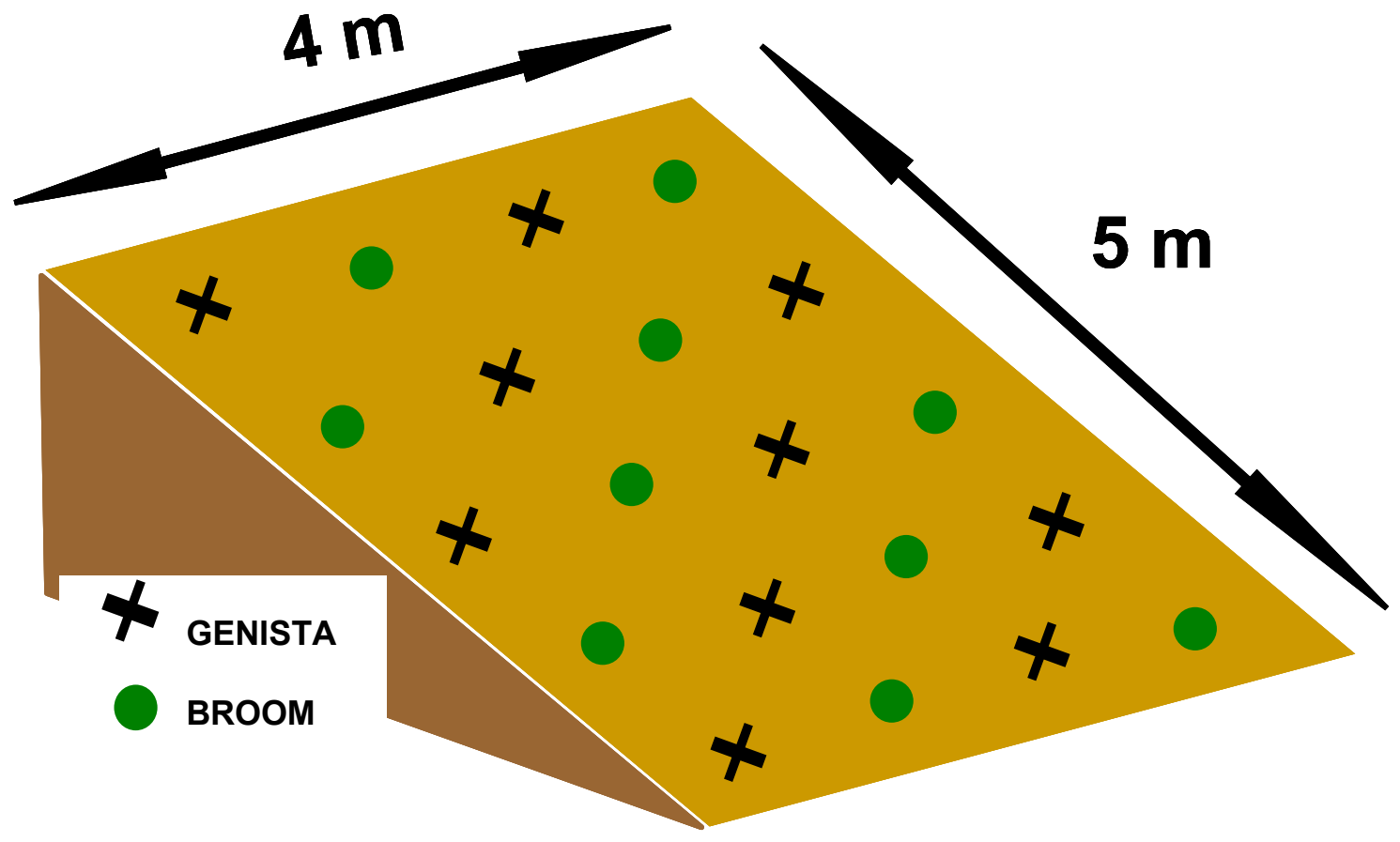

(FIGURE 1) 


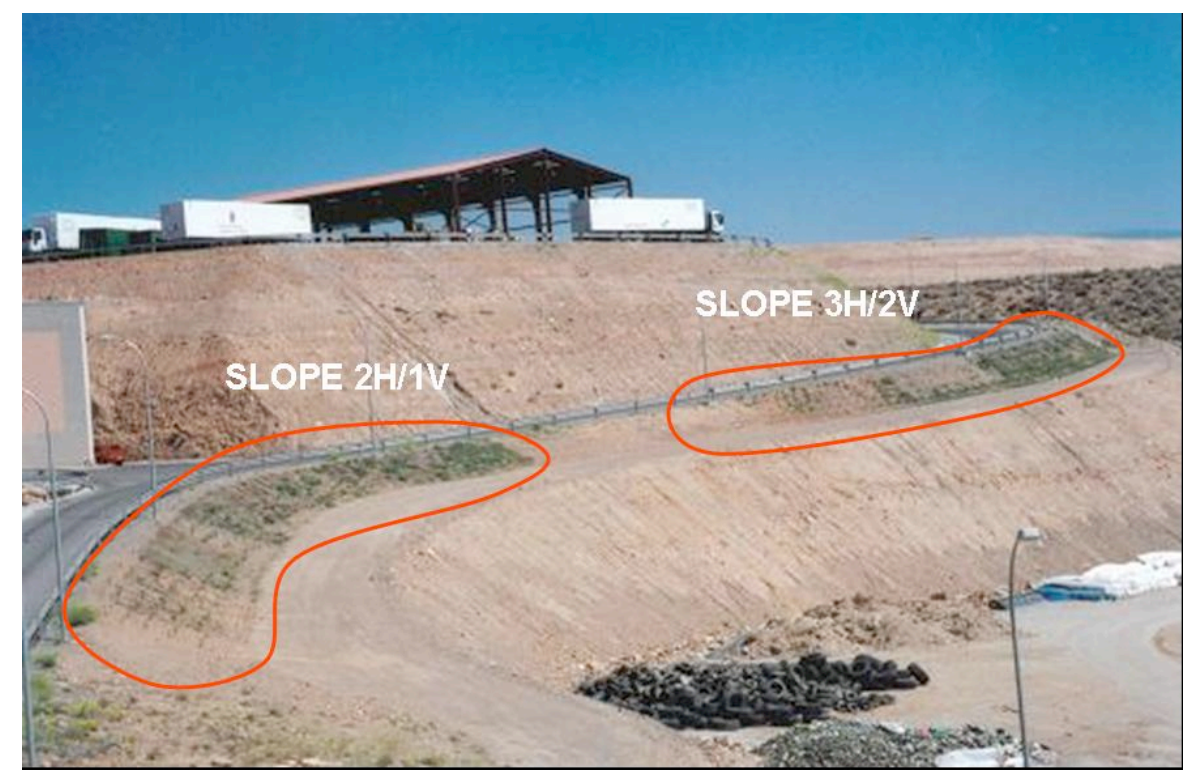

(FIGURE 2) 

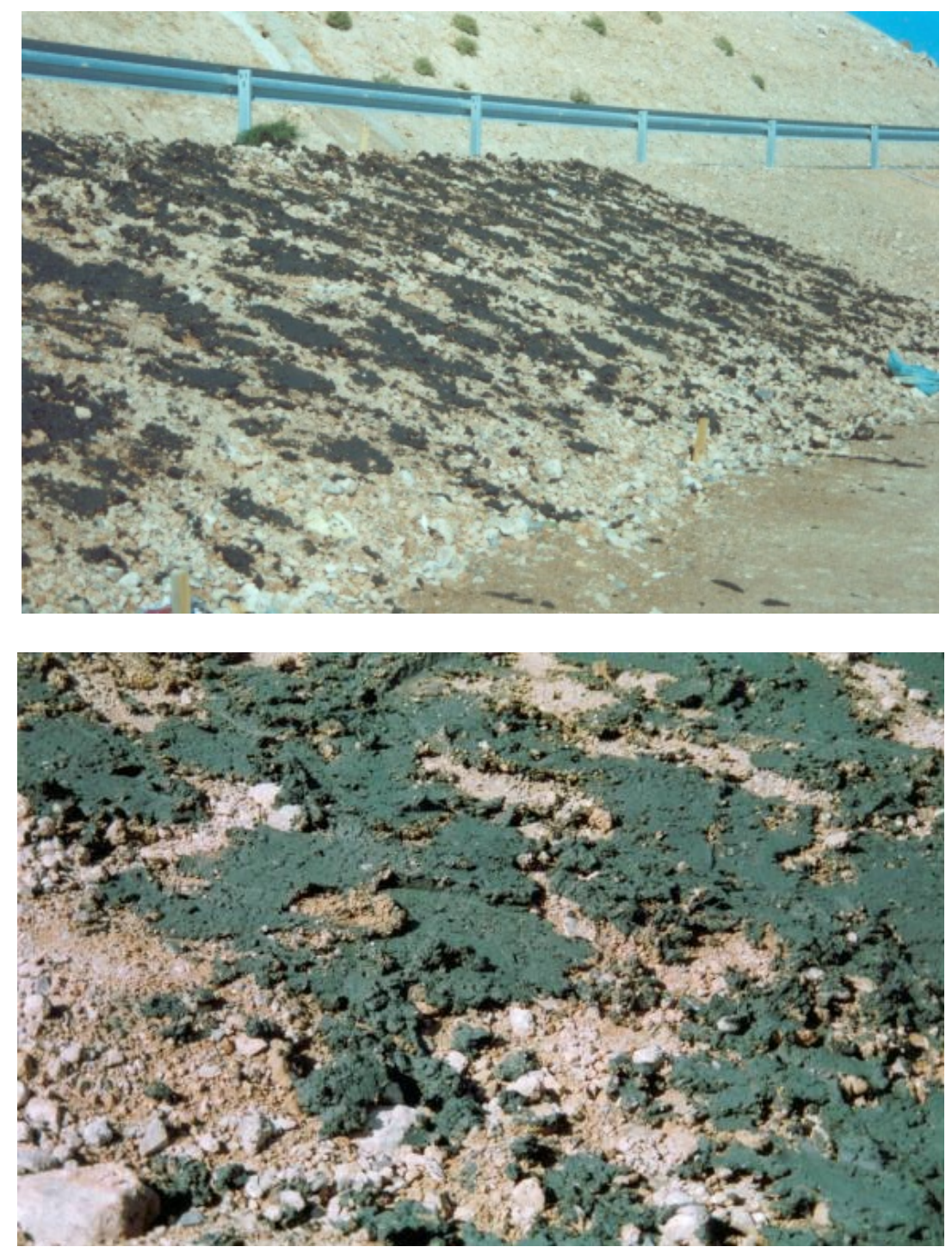

(FIGURE 3) 

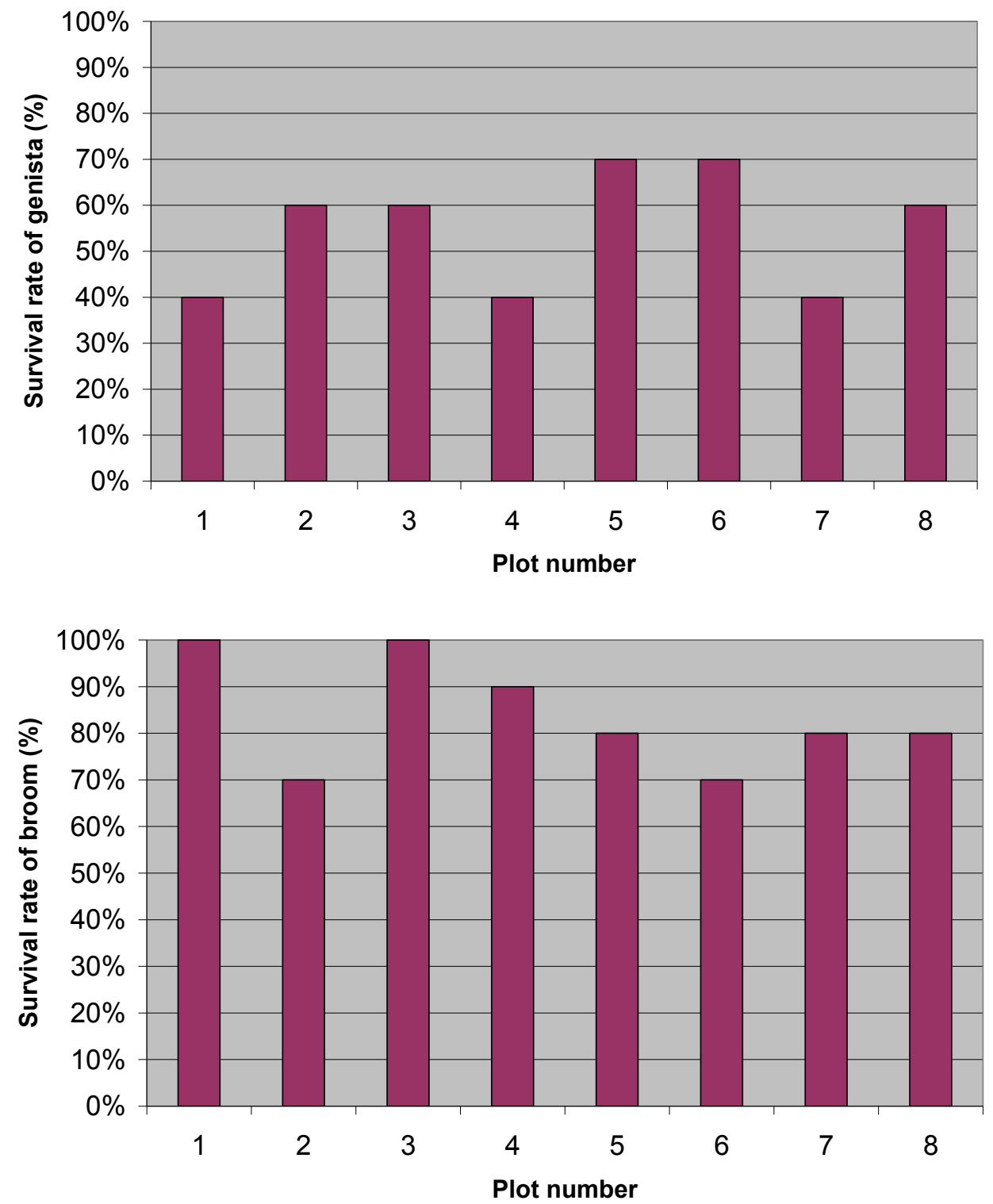

(FIGURE 4) 


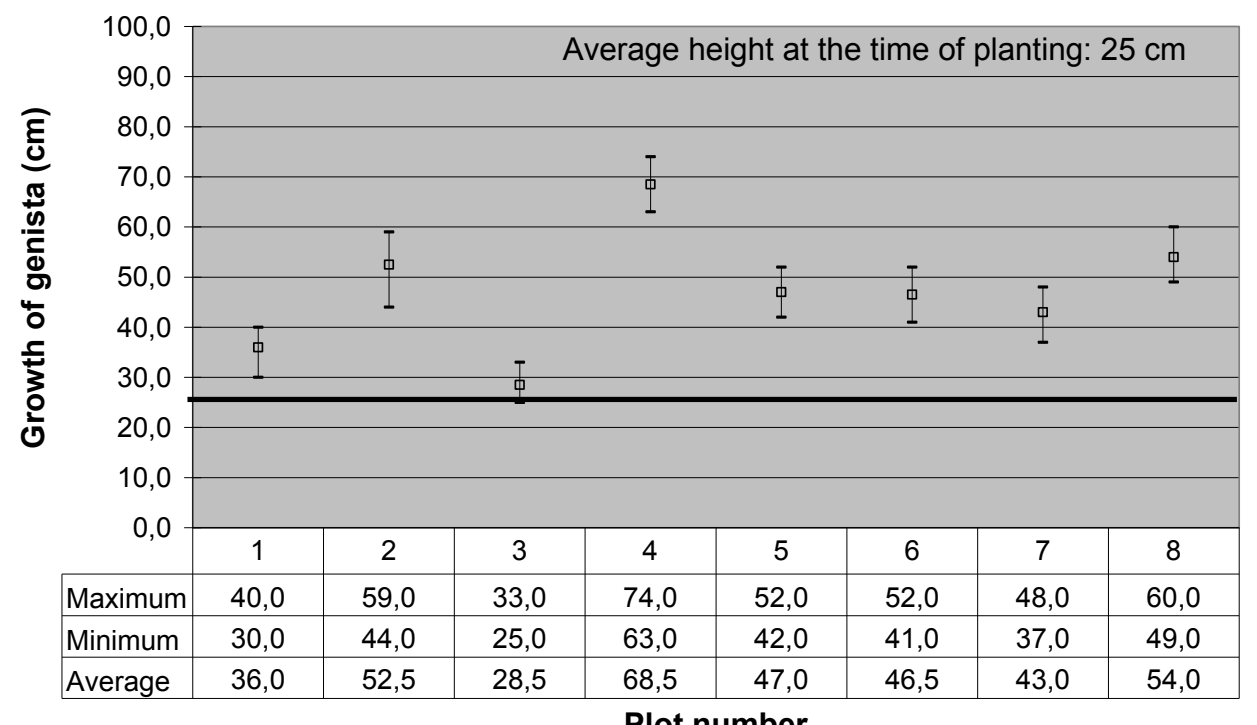

Plot number

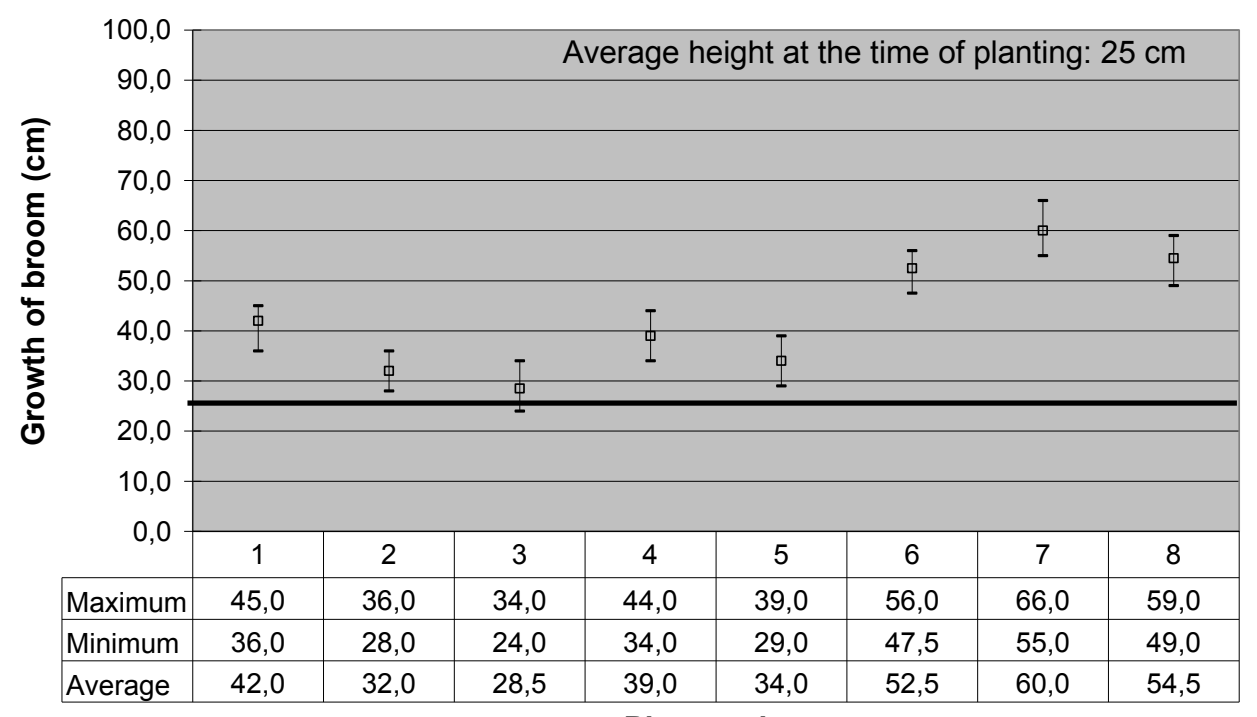

Plot number

(FIGURE 5) 

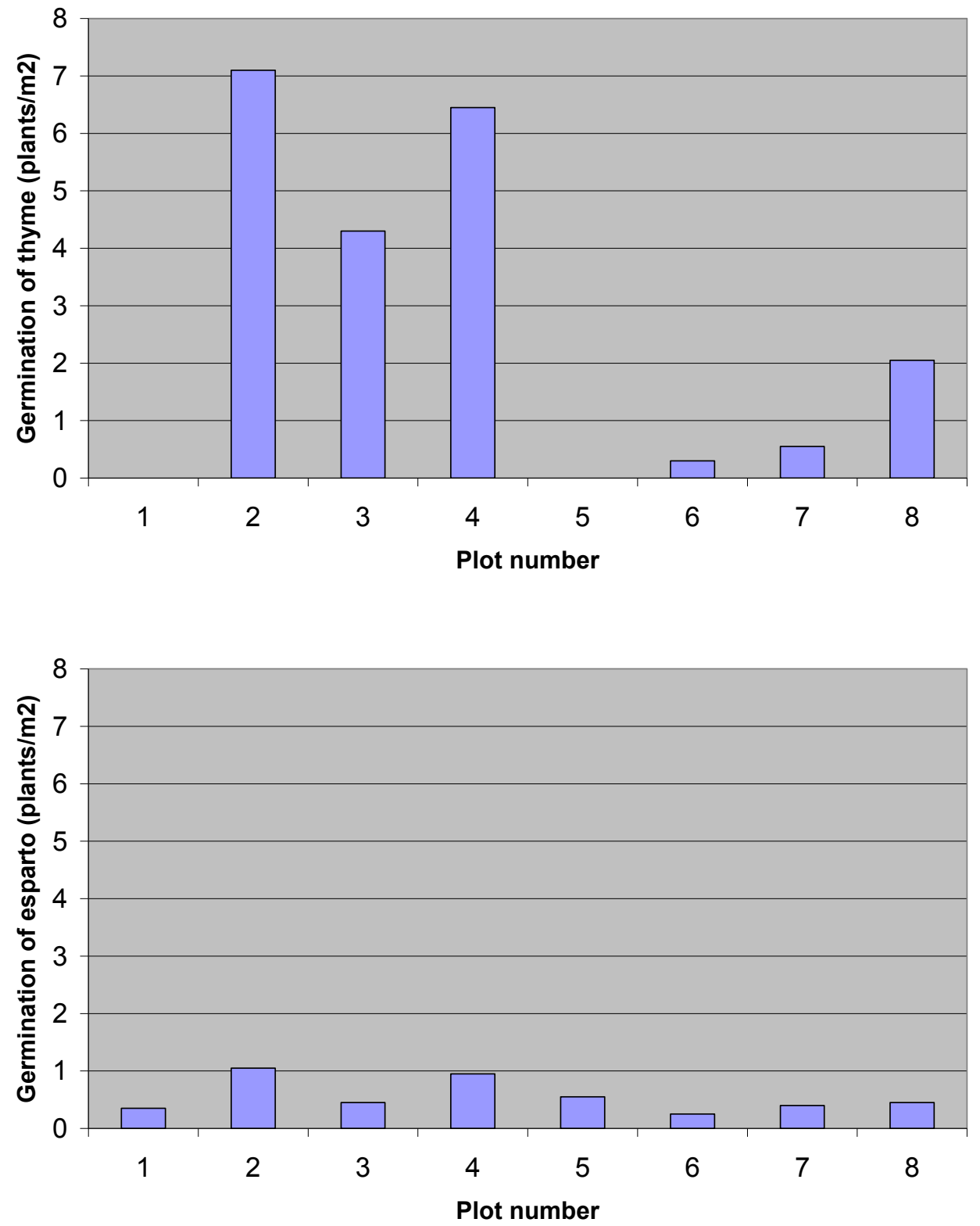

(FIGURE 6) 


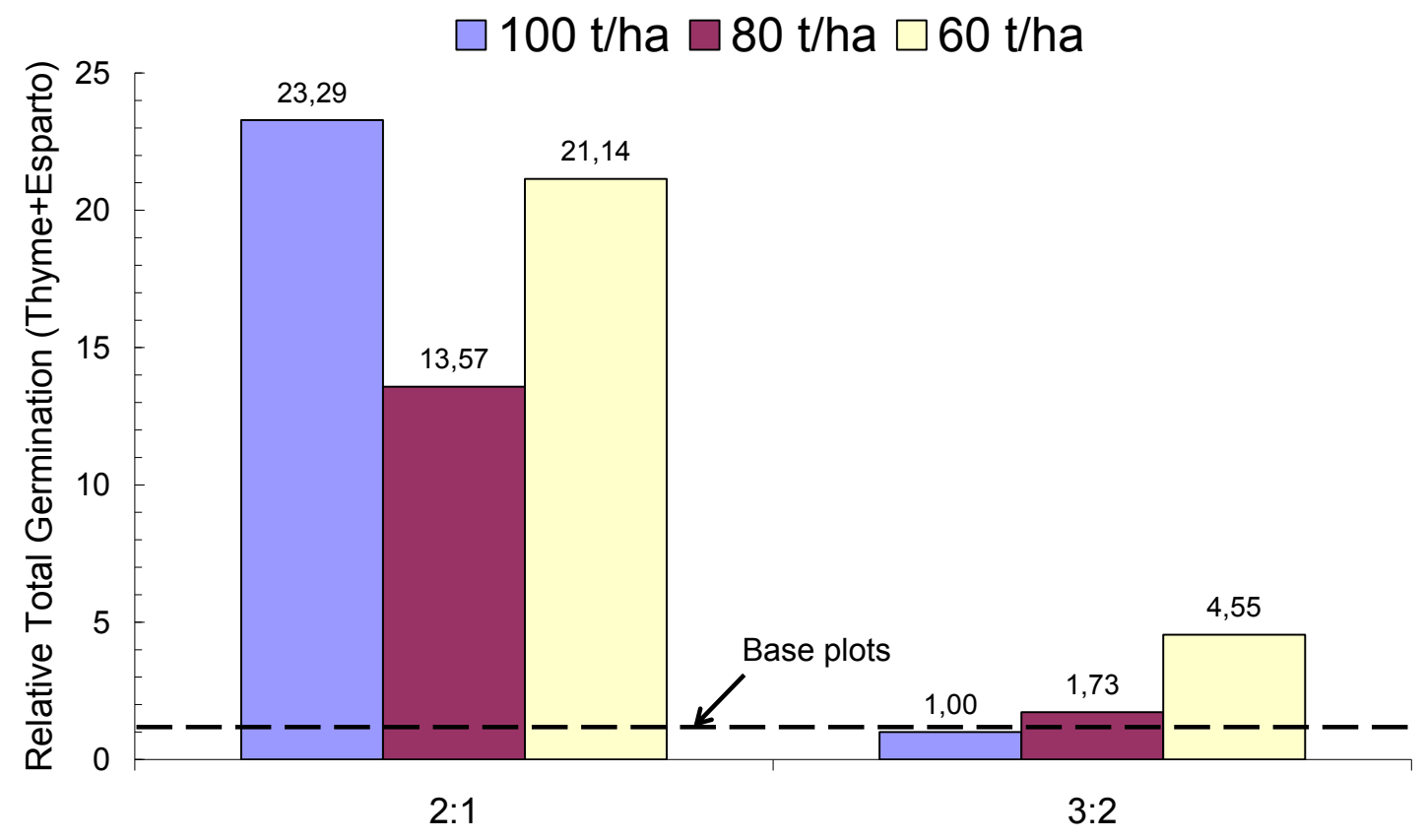

(FIGURE 7) 


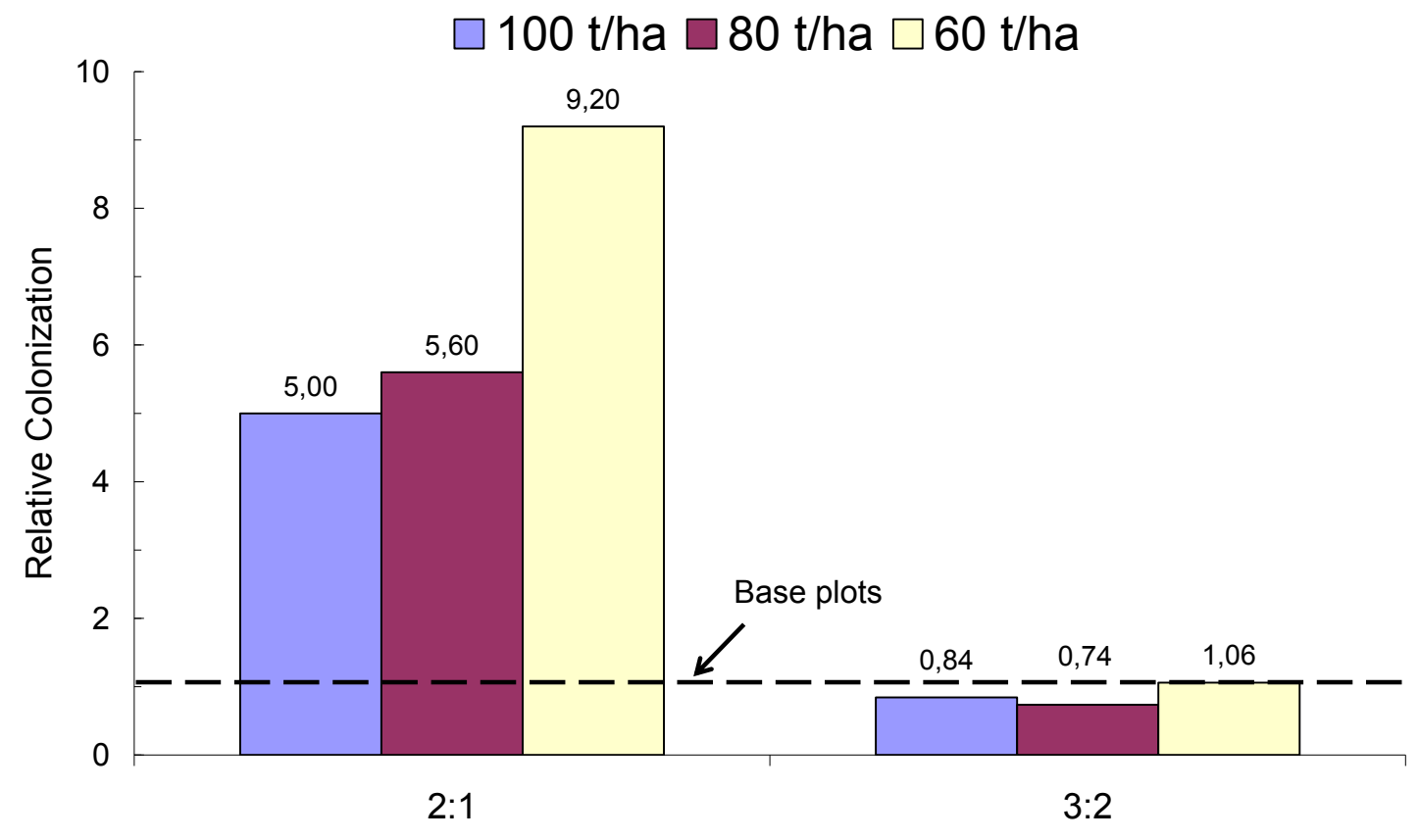

(FIGURE 8) 


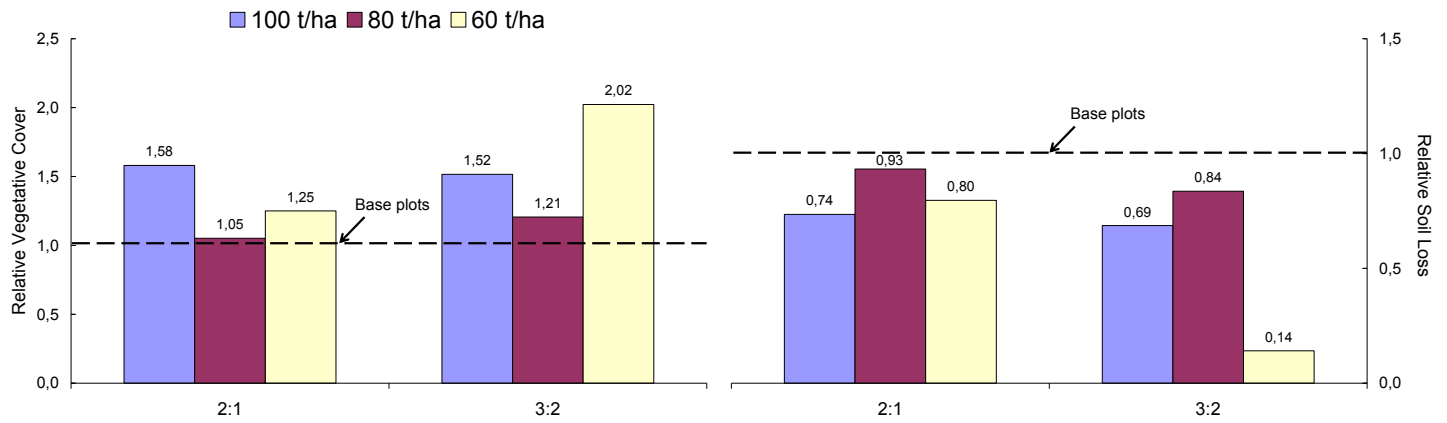

(FIGURE 9) 